\title{
Effect of ammonium salts on the biodegradation of used transformer oil using locally isolated microorganisms
}

\author{
Ayandele, A. A. ${ }^{1}$, Fagade, O. E. ${ }^{2}$ and Adenegan, A. A ${ }^{2}$ \\ ${ }^{1}$ Department of Pure and Applied Biology, Lautech, Ogbomoso, Nigeria \\ ${ }^{2}$ Department of Botany and Microbiology, University of Ibadan, Ibadan, Nigeria \\ Correspondence Author E-Mail: lizdeley@yahoo.com
}

\begin{abstract}
The effect of two different Ammonium salts; $\mathrm{NH}_{4} \mathrm{Cl}$ and $\mathrm{NH}_{4} \mathrm{NO}_{3}$ on biodegradation of used transformer oil was studied using locally isolated microorganisms. P. aeruginosa, P. chlororaphis, B. megatarium, B. alvei, Saccharomyces rouxii, Penicillium chrysogenum, and Geotrichum sp were cultured in the minimum salt medium (MSM) using used transformer oil as the sole source of carbon and energy. In the medium supplied with $\mathrm{NH}_{4} \mathrm{NO}_{3}$, Geotrichum $\mathrm{sp}$ had the highest degradation rate of $75.9 \%$, followed by the consortium of fungi with $65.3 \%$ degradation, while $P$. aeruginosa showed the least degradation of $41.05 \%$. The consortium of fungi showed the highest rate of degradation of $62.9 \%$ in medium supplied with $\mathrm{NH}_{4} \mathrm{Cl}$, followed by Geotrichum sp with $62.1 \%$, while $P$. aeruginosa also had the least degradation rate of $39.84 \%$. This suggests that the ammonium salts have different effect on the biodegradation of used transformer oil using these microorganisms.
\end{abstract}

Keywords: Ammonium salt, biodegradation, microorganisms

\section{INTRODUCTION}

Transformers oil is also known as Polychlorinated Biphenyls (PCBs). PCBs are a class of organic compound with 1 to 10 chlorine atoms attached to biphenyl and it has a general formula of $\mathrm{C}_{12} \mathrm{H}_{10-x} \mathrm{Cl}_{x}$ (Beyehok, 2005). The persistent use of PCB has not been permitted because it is highly carcinogenic and it can persist in the environment for long (Atlas and Burton, 1993). These chemicals were considered commercially valuable and produced in large quantities from the period 1929 to 1976 (Keon et al., 2007). It is used in oil-filled transformers, some types of high voltage capacitors, high voltage switches and circuit breakers. Its functions are to insulate, suppress corona and serve as coolant. Starting in the early 1970s, concerns about the toxicity of PCBs have led to their banning in many countries. Polychlorinated Biphenyls are known as the most toxic and difficult compounds to degrade. PCB was identified as environment contaminant due to transformer spillage. They were among the widespread pollutants in the global ecosystem and have been identified in the air, water sediments, fish and wild lives, human adipose tissue (Elzbieta and Krystyna, 2005).

Transformer oil is highly carcinogenic and its use has been banned in US since 1978 (Atlas and Burton, 1993). But PCBs contaminated transformer oil is still in use or in storage (UNEP, 1998, 2000). The actual and potential release of PCBs seriously threats human beings and ecosystem (Blais et al., 1998). Decontamination of transformer oil containing PCBs has been an urgent task for decades. The most conventional approach is high temperature controlled incineration, this method is highly effective but the disposal cost and the exclusion of reusable materials, as well as highly toxic by-products. Other methods include photochemical (Betterton et al.,, 2000), Ultrasonic (Rodriguez and Lafuente, 2002), microbial (Kuipers et al., 1999). Biological degradation which can take place under aerobic condition, anaerobic and the combination of aerobic and anaerobic conditions has been in focus now. In aerobic condition, the microorganisms degrade less chlorinated congeners via dioxygenase pathways compared to the anaerobic. The process converts the toxic molecules to corresponding chlorobenzoic acid, which can be mineralized to carbondioxide, water and chloride. The mineral oil hydrocarbons present in the PCBs solution influences the biodegradation process (Elzbieta and Krystyna, 2005). This work reports the effect of ammonium salt on biodegradation of used transformer oil using locally isolated microorganisms.

\section{MATERIALS AND METHODS}

Collection of Soil Samples: Soil sample was collected from PHCN transformer site and took to the 
laboratory in sterile container. $1 \mathrm{~g}$ of the soil sample was used for serial dilution and pour plate method was used for the isolation of the microorganisms. Plates were incubated at $37^{\circ} \mathrm{C}$ and $25^{\circ} \mathrm{C}$ for bacteria and fungi respectively. Incubation was done for $48 \mathrm{hrs}$ and $96 \mathrm{hrs}$ for bacteria and fungi respectively and pure isolates were stored for future use.

Isolation of oil Degrading Microorganisms: Isolated microorganisms were then streaked on Minimal Salt Medium (MSM) to determine which of them can utilize these hydrocarbons as their only source of carbon and energy. The oil agar medium consists of basal medium (mineral salt) medium; 1.8 $\mathrm{K}_{2} \mathrm{HPO}_{4}, 1.02 \mathrm{KH}_{2} \mathrm{PO}_{4}, 4.0$ Urea, $2.0 \mathrm{MgSO}_{4} .7 \mathrm{H}_{2} \mathrm{O}$, $0.1 \mathrm{NaCl}, 0.1$ Yeast Extract, $0.05 \mathrm{FeCl}_{2}$ and trace elements which are $0.1 \mathrm{H}_{3} \mathrm{BO}_{3}, 0.1 \mathrm{ZnSO}_{4}$ and 0.4 $\mathrm{MnSO}_{4} \cdot \mathrm{H}_{2} \mathrm{O}$ in 1 liter of distilled water and $2 \%$ agar agar was added to the medium before sterilization.

Plates were incubated at room temperature for 14 days. Colonies that grew very well were later subcultured on another MSM and subcultured again on NA and PDA for bacteria and fungi respectively.

Identification of Isolated Microorganisms: Microscopic and biochemical tests were carried out on the bacterial and yeast isolates to determine their probable identities while microscopic test using Methylene cotton blue for fungal identification.

Inoculum Development: Colonies of the bacterial isolates grown on agar plate's i.e. $P$. aeruginosa, $P$. chlororaphis, $B$. alvei and $B$. megatarium were washed separately into distilled water in $250 \mathrm{ml}$ Erlenmeyer flasks and the absorbance at $600 \mathrm{~nm}$ for each bacterial isolates in the distilled water was taken using Spectrophotometer, equal volume was taken from each of the bacterial isolate and the absorbance was taken to for the consortium of the bacteria. These preparations were then used for the biodegradation experiment. Fungal isolates were cultured on PDA and incubated for 5 days and scraped into the experimental bottles.

Biodegradation Experiment: $8.5 \mathrm{ml}$ of $\mathrm{MSM}$ was dispensed into each flask while $1.5 \mathrm{ml}$ of each hydrocarbon was added to the flask separately after sterilization. $1 \mathrm{ml}$ each from the already prepared bacteria suspension was used to inoculate each of the bottle and all the bottles were labeled appropriately. A control devoid of the bacteria suspension was also prepared for each of the hydrocarbon. All the experiments were prepared in duplicate. Two different nitrogen sources (Ammonium nitrate and Ammonium chloride) were used in the experiment to determine which one will favour the biodegradation process. Similar method was used for the fungal isolates. All the experiments were carried out at room temperature for 20 days.

Estimation of Hydrocarbon Oil Degradation: Two sampling bottles were taken every 5 days to determine the percentage of residual oil of the used transformer oil. The sample was first centrifuged to remove the microorganisms. The supernatant is then mixed with equal volume of $\mathrm{N}$-Hexane. The mixture was then put in a separating funnel and mixed very well until the mixture is separated into two phases; aqeous and organic phases. The organic phase was then discharged into a Petri dish and left for $24 \mathrm{hrs}$ to allow the N-Hexane to evaporate. The percentage of the residual oil that remained is then determined by using gravimetric method. In this method, the initial weight of the hydrocarbon oil is taken before the experiment and the final weight of the residual oil is also taken after the $\mathrm{N}$-Hexane has evaporated. i.e.

Weight of the hydrocarbon oil (initial ) - weight of oil after treated ( final) Wegiht of hydrocarbon oil (initial)

Absorbance of the residual oil at $600 \mathrm{~nm}$ and bacterial isolate at $600 \mathrm{~nm}$ using GENESYS 10 UV scanning spectrophotometer was also taken, bacterial growth was also determined using spread plate method, while the mycelia weight was determined for fungi

\section{RESULTS AND DISCUSSION}

Different organisms were isolated from the soil sample, but seven organisms that include, $P$. aeruginosa, $P$. chlororaphis, B. megatarium, B. alvei, Saccharomyces .rouxii, Penicillium chrysogenum, and Geotrichum sp were used for the work because they showed good growth on used transformer oil as the sole carbon and energy source. Table 1 shows the degradation rate of bacterial isolates. Consortium of the bacterial isolates had the highest degradation rate of $57.10 \%$ when the medium was supplied with $\mathrm{NH}_{4} \mathrm{Cl}$ but $P$. aeruginosa, $P$. chlororaphis and $B$. megatarium preferred $\mathrm{NH}_{4} \mathrm{NO}_{3}$ in their medium. All the fungal isolates with the exception of $S$. rouxii degrade best in the medium supplied with $\mathrm{NH}_{4} \mathrm{NO}_{3}$ (Table 2). 
Agric. Biol. J. N. Am., 2012, 3(3): 131-139

Table 1: Rate of Degradation Used transformer Oil By Bacterial Isolates

\begin{tabular}{|c|c|c|c|c|c|c|c|c|}
\hline \multirow[t]{3}{*}{ ORGANISM } & \multicolumn{8}{|c|}{ DAYS } \\
\hline & \multicolumn{2}{|c|}{5} & \multicolumn{2}{|c|}{10} & \multicolumn{2}{|c|}{15} & \multicolumn{2}{|c|}{20} \\
\hline & $\mathrm{NH}_{4} \mathrm{NO}_{3}$ & $\mathrm{NH}_{4} \mathrm{Cl}_{2}$ & $\mathrm{NH}_{4} \mathrm{NO}_{3}$ & $\mathrm{NH}_{4} \mathrm{Cl}_{2}$ & $\mathrm{NH}_{4} \mathrm{NO}_{3}$ & $\mathrm{NH}_{4} \mathrm{Cl}_{2}$ & $\mathrm{NH}_{4} \mathrm{NO}_{3}$ & $\mathrm{NH}_{4} \mathrm{Cl}_{2}$ \\
\hline$P$. aeruginosa & 27.1 & 26.37 & 36.61 & 31.77 & 38.87 & 33.63 & 41.05 & 39.84 \\
\hline P. chlororaphis & 20.48 & 23.63 & 39.76 & 39.68 & 46.05 & 40.97 & 47.82 & 46.85 \\
\hline B. megatarium & 27.34 & 22.74 & 40.16 & 33.79 & 47.90 & 44.68 & 56.94 & 53.63 \\
\hline B. alvei & 22.13 & 19.03 & 32.98 & 35.15 & 39.84 & 40.24 & 4831 & 53.55 \\
\hline Consortium & 7.42 & 25.56 & 35.24 & 39.76 & 41.05 & 45.56 & 47.45 & 57.10 \\
\hline
\end{tabular}

Table 2: Rate of Degradation of Used Transformer Oil by The fungal Isolates \begin{tabular}{|l|l|l}
\hline ORGANISM & DAYS
\end{tabular}

\begin{tabular}{|c|c|c|c|c|c|c|c|c|}
\hline \multirow[t]{3}{*}{ ORGANISM } & \multicolumn{8}{|c|}{ DAYS } \\
\hline & \multicolumn{2}{|c|}{5} & \multicolumn{2}{|c|}{10} & \multicolumn{2}{|c|}{15} & \multicolumn{2}{|c|}{20} \\
\hline & $\mathrm{NH}_{4} \mathrm{NO}_{3}$ & $\mathrm{NH}_{4} \mathrm{Cl}_{2}$ & $\mathrm{NH}_{4} \mathrm{NO}_{3}$ & $\mathrm{NH}_{4} \mathrm{Cl}_{2}$ & $\mathrm{NH}_{4} \mathrm{NO}_{3}$ & $\mathrm{NH}_{4} \mathrm{Cl}_{2}$ & $\mathrm{NH}_{4} \mathrm{NO}_{3}$ & $\mathrm{NH}_{4} \mathrm{Cl}_{2}$ \\
\hline Saccharomyces rouxii & 32.3 & 14.5 & 36.3 & 20.2 & 41.1 & 28.2 & 44.4 & 54.8 \\
\hline Penicillium chrysogenum & 39.5 & 38.7 & 41.1 & 41.9 & 46.0 & 45.2 & 55.6 & 49.2 \\
\hline Geotrichum sp & 45.2 & 25.8 & 54.8 & 34.7 & 66.1 & 50.8 & 75.9 & 62.1 \\
\hline Consortium & 25.1 & 36.3 & 41.1 & 38.7 & 50.8 & 48.4 & 65.3 & 62.9 \\
\hline
\end{tabular}

The degradation rate of these organisms differed when the medium was supplied with different ammonium salts, although the majority of the organisms performed better in the medium supplied with $\mathrm{NH}_{4} \mathrm{NO}_{3}$ and this agreed with the findings of Brook et al., 2001, Ciawi and Shanti, 2000 and Jorio et al., 2000. Result gotten from this work also showed that fungal isolates were able to utilized used transformer oil than the bacterial isolates. This is consistent with the observations of Aislabie et al., 2000 and Gramss et al., 1999 that fungi now play important role in the degradation of hydrocarbons since their metabolism can take place under different conditions and fungi can also grow under toxic conditions.

Tables 3 and 4 show the biomass of the bacterial isolates and the mycelia weight of the fungal isolates, it was observed from the result that there was gradual increase in these organisms population throughout the 20 days of experiment. This also agreed with the findings of Antai, 1990 and Ohenhen et al., 2006.

Table 3: $\quad$ Total Bacteria count in Minimum Salt Medium Using Used Transformer Oil as the Substrate

\begin{tabular}{|c|c|c|c|c|c|c|c|c|}
\hline \multirow[t]{3}{*}{ ORGANISM } & \multicolumn{8}{|c|}{ DAYS } \\
\hline & \multicolumn{2}{|c|}{$\stackrel{5}{\left(\mathrm{Cfu} / \mathrm{ml} \times 10^{3}\right)}$} & \multicolumn{2}{|c|}{$\begin{array}{c}10 \\
\left(\mathrm{Cfu} / \mathrm{ml} \times 10^{3}\right)\end{array}$} & \multicolumn{2}{|c|}{$\begin{array}{c}15 \\
\left(\mathrm{Cfu} / \mathrm{ml} \times 10^{3}\right)\end{array}$} & \multicolumn{2}{|c|}{$\begin{array}{c}20 \\
\left(\mathrm{Cfu} / \mathrm{ml} \times 10^{3}\right)\end{array}$} \\
\hline & $\mathrm{NH}_{4} \mathrm{NO}_{3}$ & $\mathrm{NH}_{4} \mathrm{Cl}_{2}$ & $\mathrm{NH}_{4} \mathrm{NO}_{3}$ & $\mathrm{NH}_{4} \mathrm{Cl}_{2}$ & $\mathrm{NH}_{4} \mathrm{NO}_{3}$ & $\mathrm{NH}_{4} \mathrm{Cl}_{2}$ & $\mathrm{NH}_{4} \mathrm{NO}_{3}$ & $\mathrm{NH}_{4} \mathrm{Cl}_{2}$ \\
\hline P. aeruginosa & 68 & 96 & 83 & 109 & 106 & 115 & 138 & 153 \\
\hline B. megatarium & 79 & 98 & 97 & 112 & 110 & 107 & 129 & 115 \\
\hline B. alvei & 95 & 92 & 105 & 97 & 101 & 122 & 135 & 144 \\
\hline P. chlororaphis & 87 & 97 & 96 & 87 & 132 & 142 & 147 & 167 \\
\hline Consortium & 97 & 97 & 109 & 74 & 148 & 110 & 168 & 135 \\
\hline
\end{tabular}

Table 4: Mycelia Weight of Fungal Isolates in Used Transformer Oil ORGANISM

\begin{tabular}{|c|c|c|c|c|c|c|c|c|}
\hline \multirow[t]{3}{*}{ ORGANISM } & \multicolumn{8}{|c|}{ DAYS } \\
\hline & \multicolumn{2}{|c|}{5} & \multicolumn{2}{|c|}{10} & \multicolumn{2}{|c|}{15} & \multicolumn{2}{|c|}{20} \\
\hline & $\mathrm{NH}_{4} \mathrm{NO}_{3}$ & $\mathrm{NH}_{4} \mathrm{Cl}_{2}$ & $\mathrm{NH}_{4} \mathrm{NO}_{3}$ & $\mathrm{NH}_{4} \mathrm{Cl}_{2}$ & $\mathrm{NH}_{4} \mathrm{NO}_{3}$ & $\mathrm{NH}_{4} \mathrm{Cl}_{2}$ & $\mathrm{NH}_{4} \mathrm{NO}_{3}$ & $\mathrm{NH}_{4} \mathrm{Cl}_{2}$ \\
\hline Penicillium chrysogenum & 0.53 & 0.63 & 0.63 & 0.72 & 0.66 & 0.76 & 0.68 & 0.82 \\
\hline Geotrichum sp & 0.43 & 0.61 & 0.54 & 0.74 & 0.76 & 0.78 & 0.88 & 0.84 \\
\hline Consortium & 0.62 & 0.66 & 0.64 & 0.77 & 0.74 & 0.79 & 0.81 & 0.87 \\
\hline
\end{tabular}




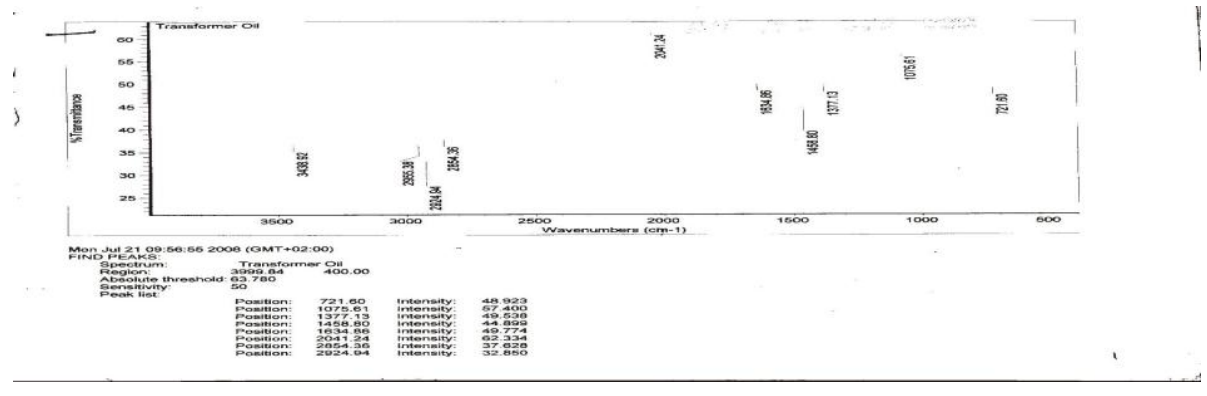

Fig 1: IR spectra of undegraded used transformer oil

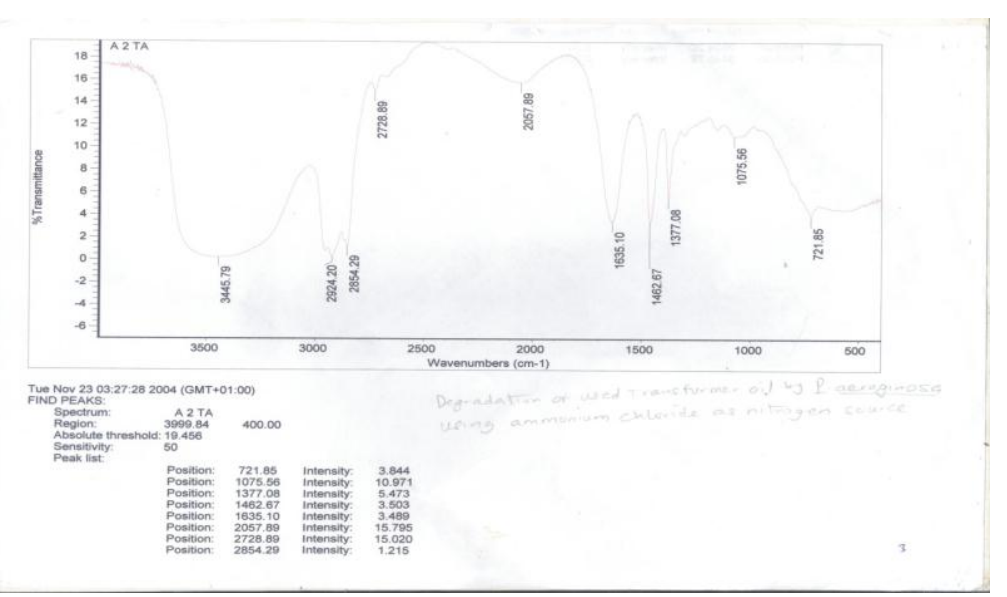

Fig 3: IR spectra of residual oil from $P$. aeruginosa $\left(\mathrm{NH}_{4} \mathrm{Cl}\right)$

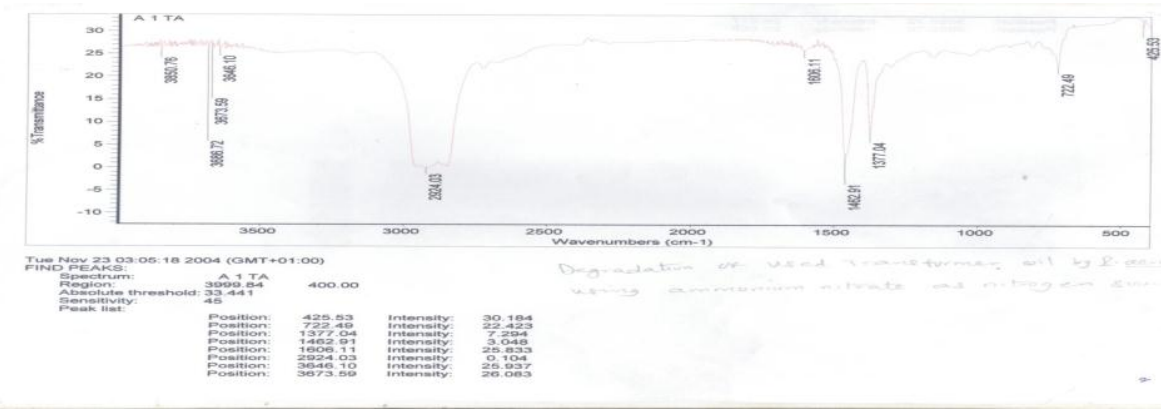

Fig 2: IR spectra of residual oil from $P$. aeruginosa $\left(\mathrm{NH}_{4} \mathrm{NO}_{3}\right)$
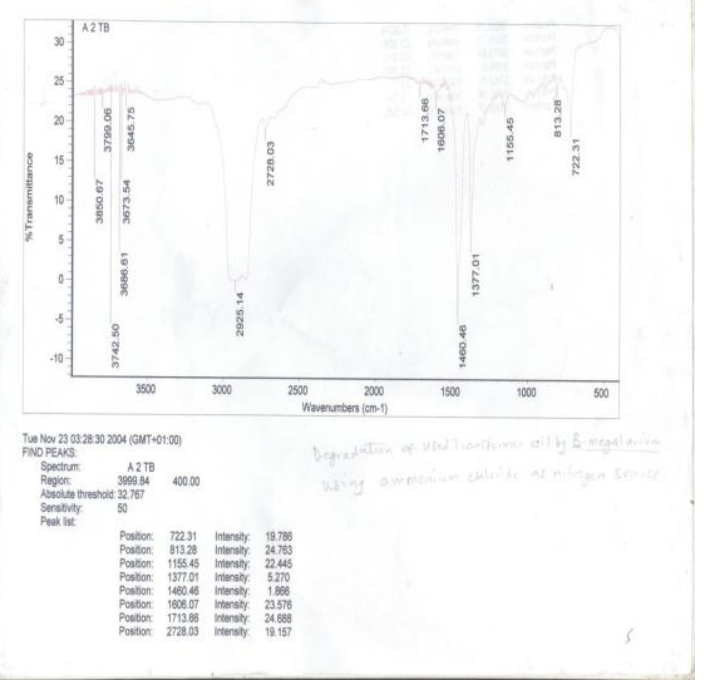

Fig 4: IR spectra of residual oil from B. megatarium $\left(\mathrm{NH}_{4} \mathrm{NO}_{3}\right)$ 
Agric. Biol. J. N. Am., 2012, 3(3): 131-139

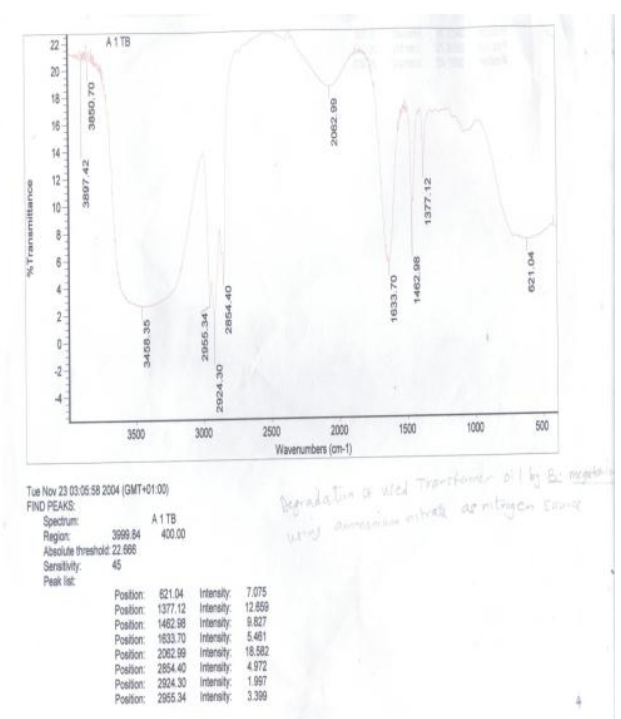

Fig 5: IR spectra of residual oil from B. megatarium $\left(\mathrm{NH}_{4} \mathrm{Cl}\right)$

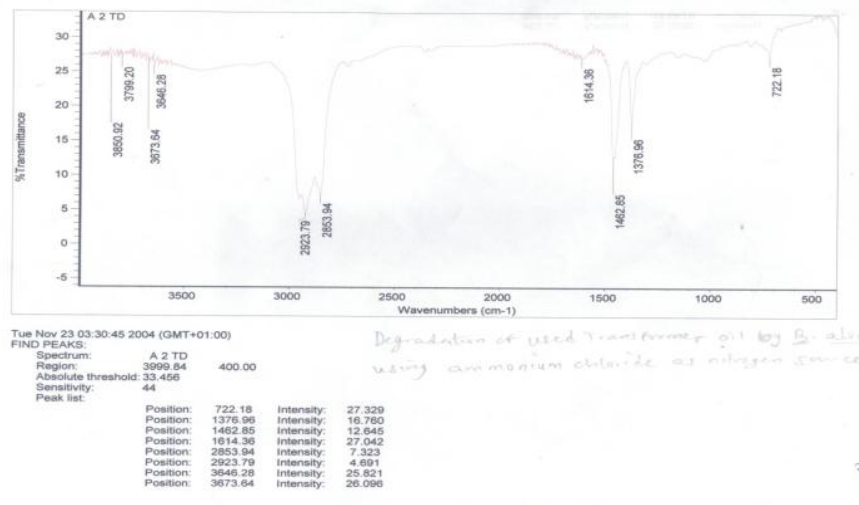

Fig 7: IR spectra of residual oil from B. alvei $\left(\mathrm{NH}_{4} \mathrm{Cl}\right)$ $\left(\mathrm{NH}_{4} \mathrm{NO}_{3}\right)$

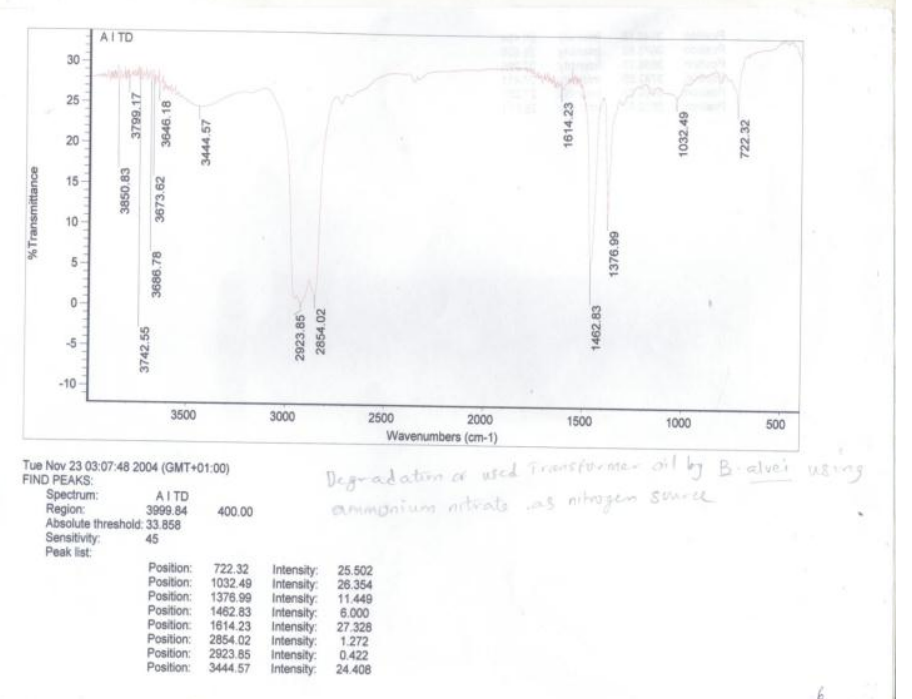

Fig 6: IR spectra of residual oil from B. alvei $\left(\mathrm{H}_{4} \mathrm{NO}_{3}\right.$

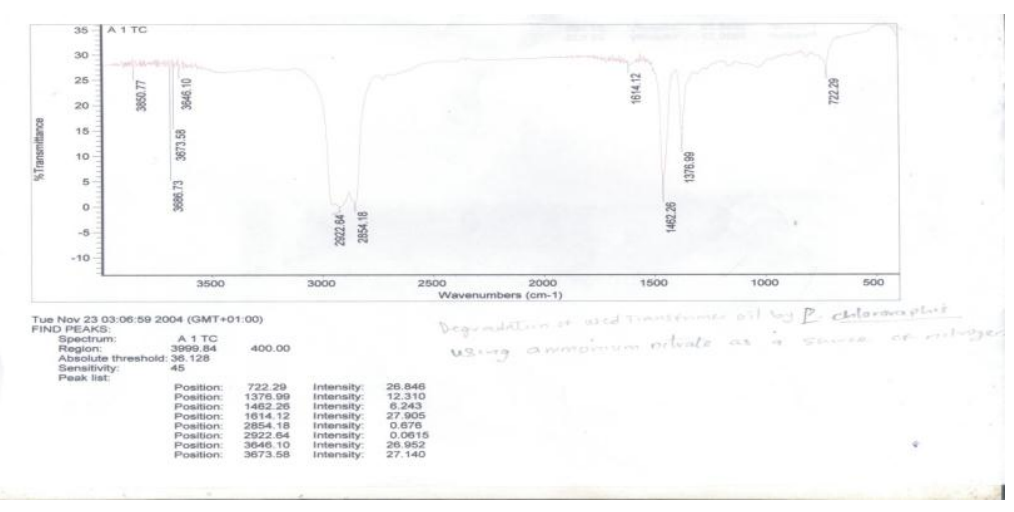

Fig 8: IR spectra of residual oil from P. chlororaphis 
Agric. Biol. J. N. Am., 2012, 3(3): 131-139

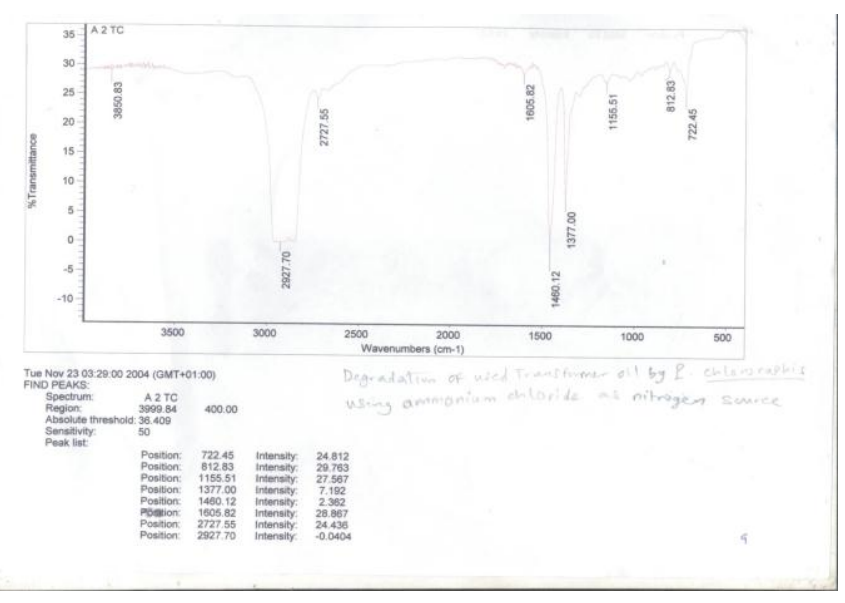

Fig 9: IR spectra of residual oil from P. chlororaphis $\left(\mathrm{NH}_{4} \mathrm{Cl}\right)$

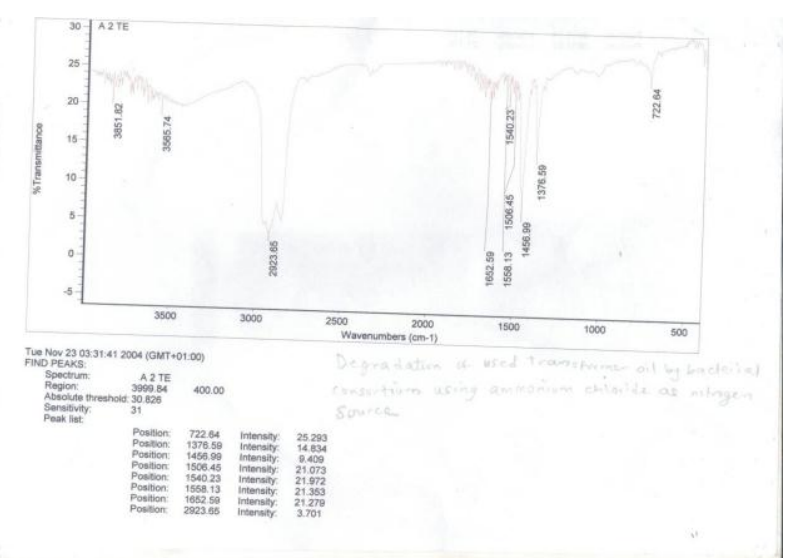

Fig 11: IR spectra of residual oil from bacterial consortium $\left(\mathrm{NH}_{4} \mathrm{Cl}\right)$

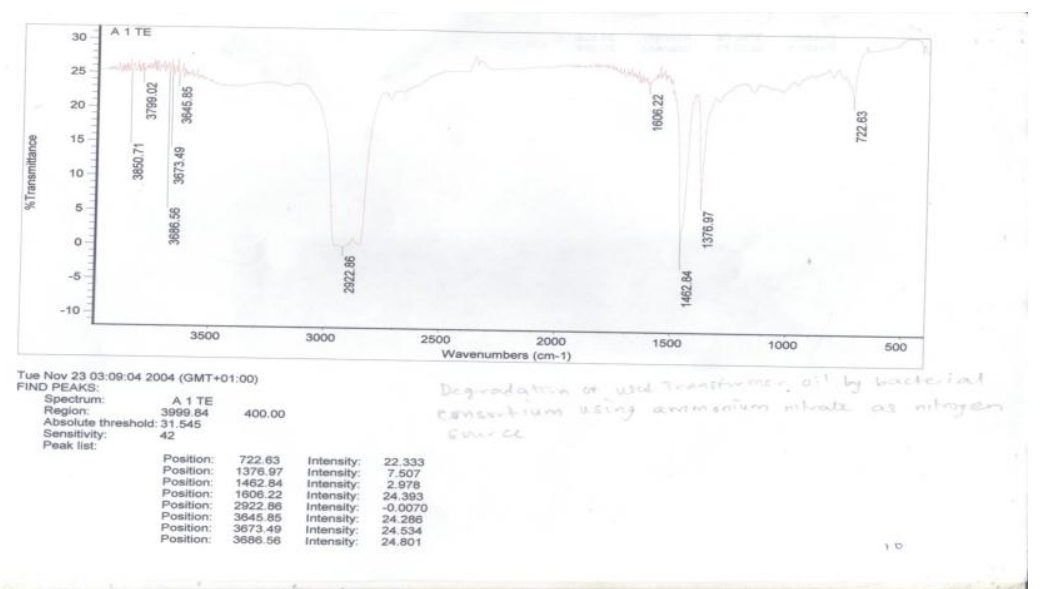

Fig 10: IR spectra of residual oil from bacterial consortium $\left(\mathrm{NH}_{4} \mathrm{NO}_{3}\right)$

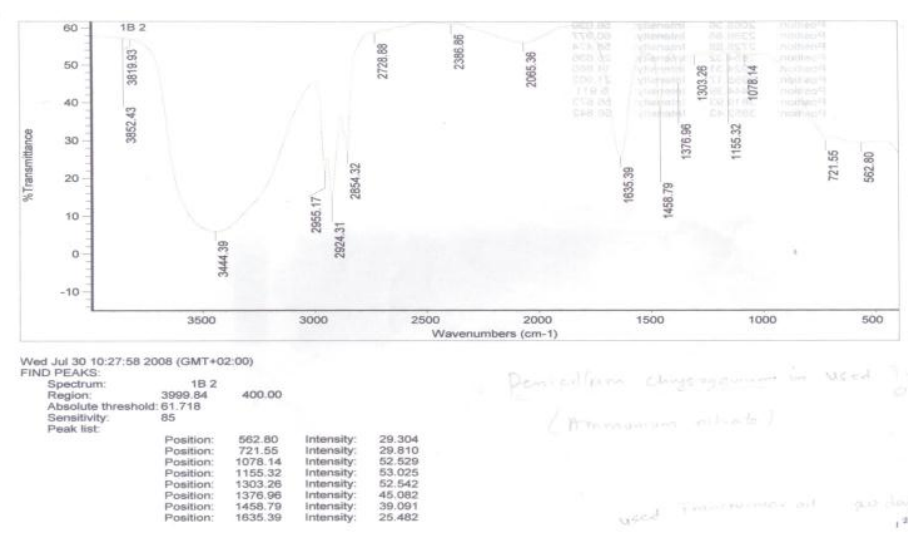

Fig 12: IR spectra of residual oil from $P$. chrysogenum $\left(\mathrm{NH}_{4} \mathrm{NO}_{3}\right)$ 
Agric. Biol. J. N. Am., 2012, 3(3): 131-139

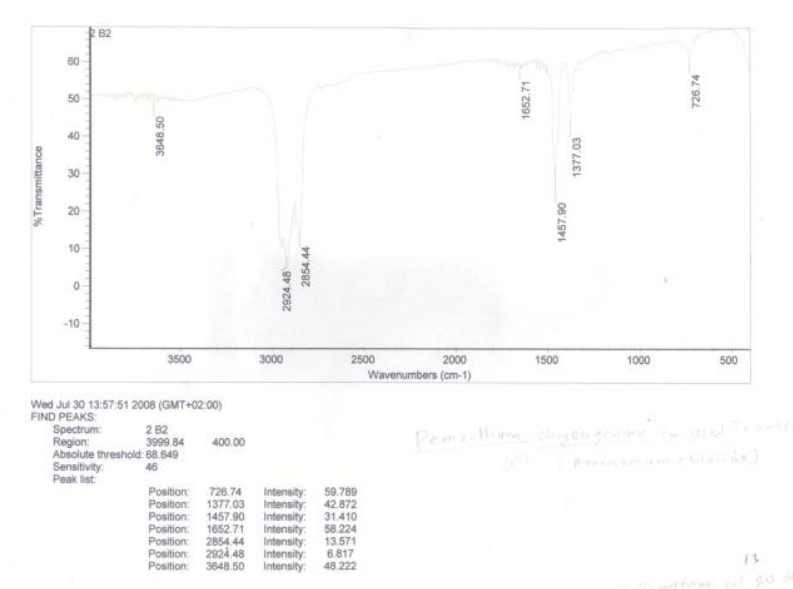

Fig 13: IR spectra of residual oil from $P$. chrysogenum $\left(\mathrm{NH}_{4} \mathrm{Cl}\right)$

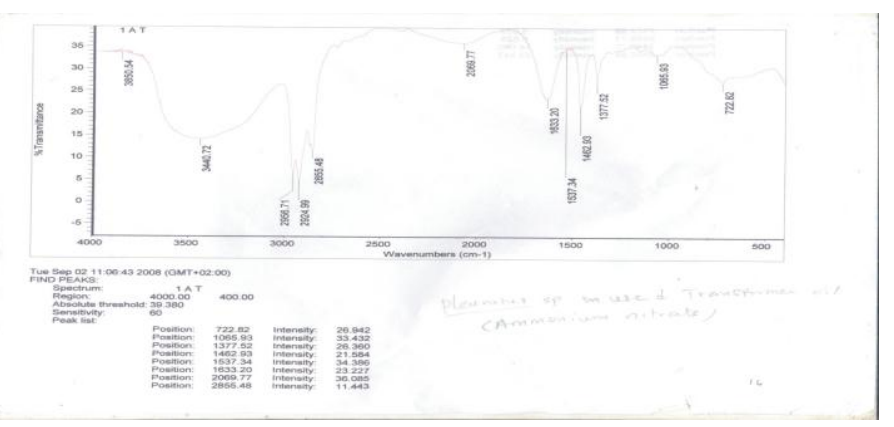

Fig 15: IR spectra of residual oil from S. rouxii $\left(\mathrm{NH}_{4} \mathrm{Cl}\right)$

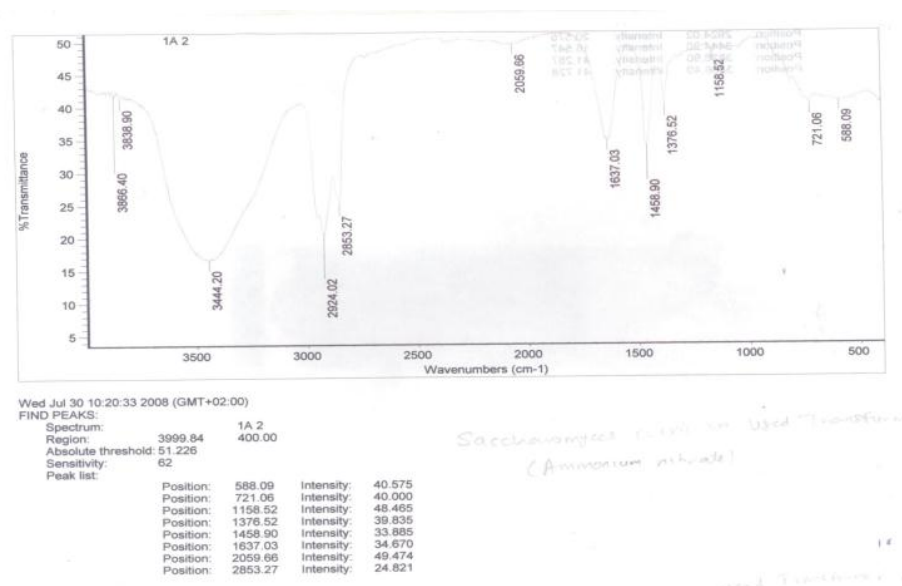

Fig 14: IR spectra of residual oil from S. rouxii $\left(\mathrm{NH}_{4} \mathrm{NO}_{3}\right)$

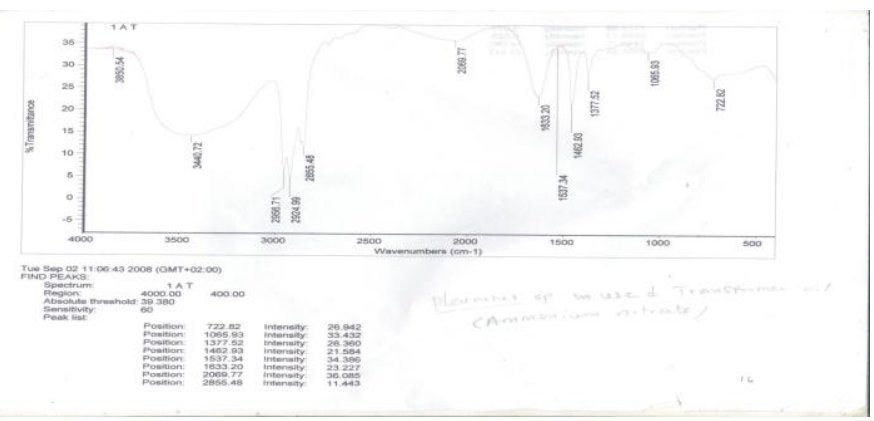

Fig 16: IR spectra of residual oil from Geotrichum sp $\left(\mathrm{NH}_{4} \mathrm{NO}_{3}\right)$ 
Agric. Biol. J. N. Am., 2012, 3(3): 131-139

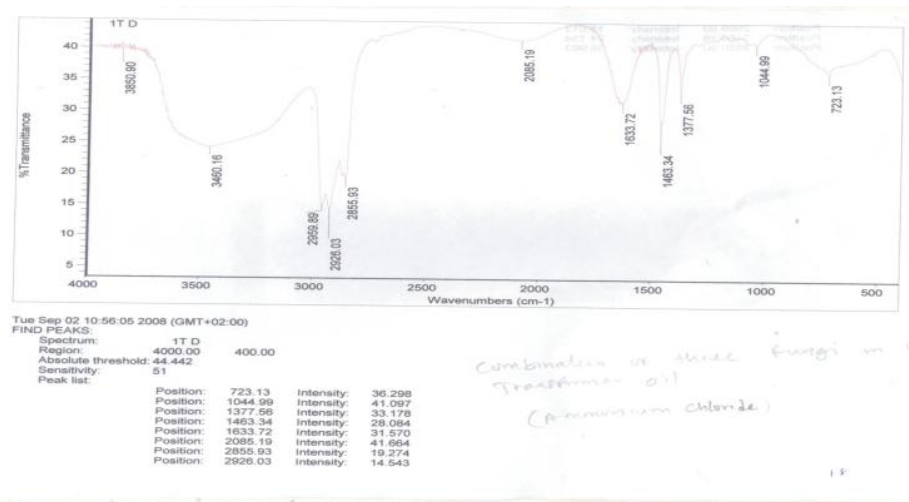

Fig 17: IR spectra of residual oil from Geotrichum sp $\left(\mathrm{NH}_{4} \mathrm{Cl}\right)$

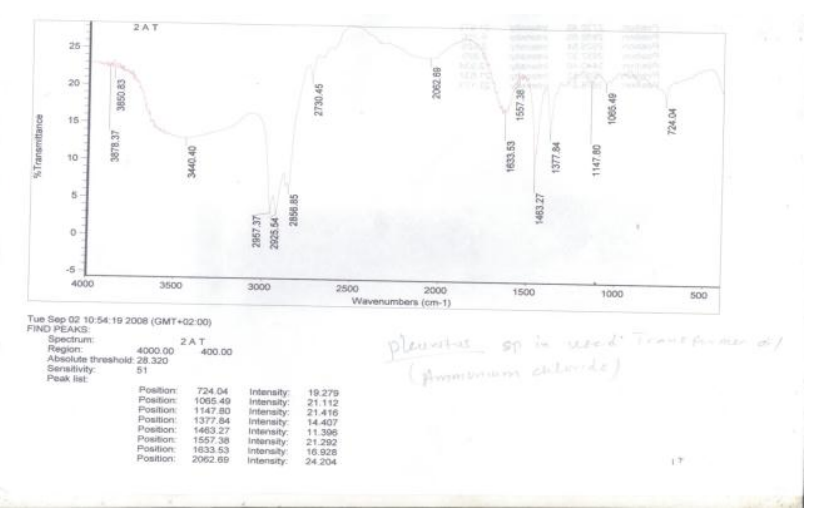

Fig 19: IR spectra of residual oil from fungal consortium $\left(\mathrm{NH}_{4} \mathrm{Cl}\right)$

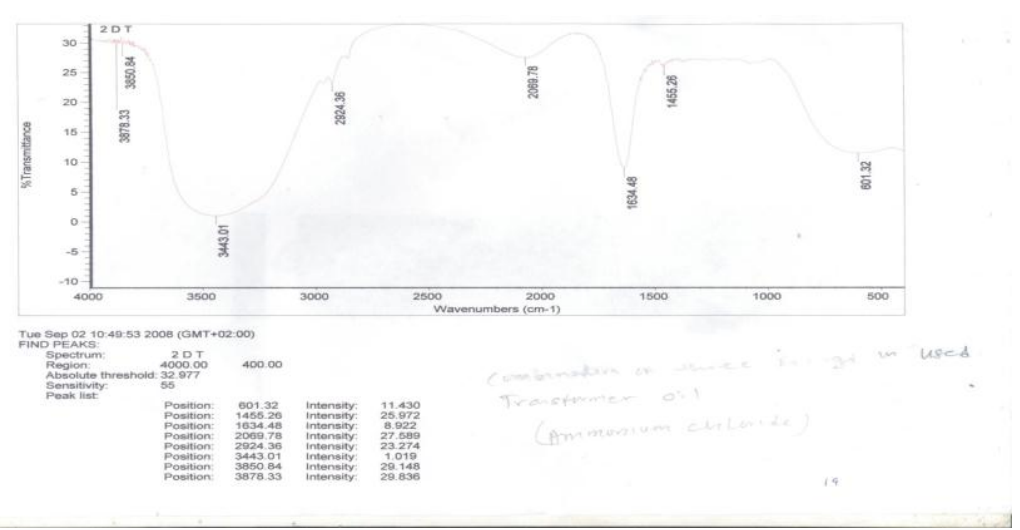

Fig 18: IR spectra of residual oil from fungal consortium $\left(\mathrm{NH}_{4} \mathrm{Cl}\right.$ 
Infra-red of the control and residual oil reveals several absorption peaks and shifts in the maximum wavelength of absorption which confirms the modification of the original oil by microbial treatment (fig 1-19). The peak of $3850.71 \mathrm{~cm}^{-1}$ observed in most of residual showed that the residual oils contain mainly $\mathrm{OH}$ which may be due to water or alcohol, the peak of $721.60 \mathrm{~cm}^{-1}$ observed in the control showed the presence of aromatic compound due to benzene ring, although this peak is also observed in some residual oils but it has reduced compared with the intensity observed in the control. Peaks of $2959.89 \mathrm{~cm}^{-1}$ which are due to $\mathrm{C}-\mathrm{H}$ stretching are also observed, $1463.53 \mathrm{~cm}^{-1}, 1606.22 \mathrm{~cm}^{-1}, 2728.88 \mathrm{~cm}^{-1}$ due to $\mathrm{C}-\mathrm{H}$ deformation, conjugated cyclic and $\mathrm{CHO}$ are also observed.

This study showed that these organisms were able to utilize used transformer oil but their degradation rate is mostly enhanced when $\mathrm{NH}_{4} \mathrm{NO}_{3}$ is supplied in their medium. In conclusion, different ammonium salts like urea can also be used in order to ascertain which of these salts will favour the degradation rate of these organisms most.

\section{REFERENCES}

Antai, S. P. (1990). Biodegradation of Bonny Light crude oil by Bacillus species and Pseudomonas species. Waste Manage. 10: 61-64.

Aislabie, J., Fraser, R., Duncan, S., and Farrell, R. (2001). Effects of oil spills on Microbial heterotrophs in Antarctica. Polar Biol. 24: 308-313.

Atlas, R.M and Burton, R. (1993). Microbial Ecology: Fundamental Applications, $3^{\text {rd }}$ Edition. Pp. 388-390. The Benjamin/Cummings Publishing Company Inc. New York.

Betterton, Eric A., Hollan, N., Arnold, R.G., Gogosha, S., Mckim, K., Liu, Z.J. (2000) Acetone-photosensitized reduction of carbon tetrachloride by 2- propanol in Aqueous solution. Environ. Sci. Technol. 34, 12291233

Blais, J.M., Schindler, D.W., Muir, D.C.G., Kimpe, L.E., Donald, D.B., Rosenberg, B. (1998). Accumulation of persistent organochloride compounds in mountains of Western Canada. Nature 359 (8), 585-588.

Brook, T., Stiver, W.H., and Zytner, R.G. (2001). Biodegradation of diesel fuel in Soil under various nitrogen addition regimes. Soil Sediment Contam. 10(5): 539-553.
Ciawi, Y. and Santi, H.C. (2000). The effect of carbon and nitrogen ratio and the Presence of minor element on the degradation of crude oil by Pseudomonas Sp. Arthrobacter sp. and Mycobacterium sp. International Symposium on Marin Biotechnology, Jakarta.

Elzbieta Sobieecka and Krystyna Cedzynska. (2005). Biodegradation Effects of waste Transformer oil polluted of PCBs in various culture conditions. Proceedings of The $9^{\text {th }}$ International conference on Environmental Science and Technology. Rhodes Island, Greece. 1-3.

Gramss, G., Voight, K., and Kirsche, B. (1999). Degradation of polycyclic aromatic Hydrocarbons with three to seven aromatic rings by higher fungi in sterile and Unsterile soils. Biodegradation, 10: 51-62.

Jorio, H., Bibeau, L., and Heitz, M. (2000). Biofiltration of air contaminated by Styrene: effect of nitrogen supply, gas flow rate, and inlet concentration. Environ. Sci. Technol. 34: 1764-1771.

Keon, S. R.; Sang, H. B.; Jong Ha, C.; Young Pyo, H.; Young Tae, R.; Jae, S. S.;Ding, S. L. and Hwsung, L. (2007). Destruction and removal of PCBs in Waste Transformer oil by a chemical Dechlorination process. Bull. Korean Chem. Soc. Vol 28, No 4. 520-528.

Kuipers, B., Cullen, W.R., Mohn, W.W (1999). Reductive dechlorination of Nonachlorobiphenyls and selected octachlorobiphenyls by microbial Enrichment cultures. Environ. Sci. Technol. 33, 3579-3585.

Ohenhen, E. R; Ikolo, F. E. and Uzeh, E. R. (2000). Growth response of Bacterial isolate on crude oil. Am. J. Sci. 2 (2): 13-16.

Rodriguez, J.G. and Lafuente, A., 2002. A new advanced method for heterogenous Catalysed dechlorination of polychlorinated biphenyls in hydrocarbon Solvent. Tetrahedron Lett. 43, 9581-9583.

The Environment Programme of the United Nations. (1998). (accessed December, 1998). Inventory of worldwide PCB destruction capacity. Available from:

http://irptc.unep.ch/pops/pdf/pcbrpt.pdf.

The Environment Programme of the United Nation, 2000 (accessed August, 2000). Survey of currently available nonincineration PCB destruction technologies.Available from:

<http://irptc.unep.ch/pops/pdf/pcbrpt.pdf> 